\title{
Thyroid hormones promote cell differentiation and up-regulate the expression of the seladin-1 gene in in vitro models of human neuronal precursors
}

\author{
S Benvenuti*, P Luciani*, I Cellai, C Deledda, S Baglioni, R Saccardi ${ }^{1}$, S Urbani ${ }^{1}$, F Francini ${ }^{2}$, R Squecco ${ }^{2}$, \\ C Giuliani, G B Vannelli ${ }^{3}$, M Serio, A Pinchera ${ }^{4}$ and A Peri
}

Endocrine Unit, Department of Clinical Physiopathology, Center for Research, Transfer and High Education on Chronic, Inflammatory, Degenerative and Neoplastic Disorders for the Development of Novel Therapies' (DENOThe), University of Florence, Viale Pieraccini, 6, 50139 Florence, Italy

${ }^{1}$ Department of Haematology, Careggi Hospital, 50139 Florence, Italy

Departments of ${ }^{2}$ Physiological Sciences and ${ }^{3}$ Anatomy, Histology, and Forensic Medicine, University of Florence, 50139 Florence, Italy

${ }^{4}$ Section of Endocrinology, Department of Endocrinology and Metabolism, AMBISEN Center, High Technology Center for the Study of the Environmental Damage of the Endocrine and Nervous Systems, University of Pisa, 56100 Pisa, Italy

(Correspondence should be addressed to A Peri; Email: a.peri@dfc.unifi.it)

*(S Benvenuti and P Luciani equally contributed to this work)

\begin{abstract}
Thyroid hormones (TH) play an important role in the development of human brain, by regulating the expression of specific genes. Selective Alzheimer's disease indicator-1 (seladin-1) is a recently discovered gene with neuroprotective properties, which has been found to be down-regulated in brain regions affected by Alzheimer's disease. Seladin-1 has anti-apoptotic properties mainly due to the inhibition of the activation of caspase 3. The aim of this study was to determine whether seladin-1 may be regarded as a new mediator of the effects of $\mathrm{TH}$ in the developing brain. In order to demonstrate this hypothesis, the effects of $\mathrm{TH}$ both on cell differentiation and on the expression of seladin-1 were assessed in two different cell models, i.e. fetal human neuroepithelial cells (FNC) and human mesenchymal stem cells (hMSC), which can be differentiated into neurons. 3,3',5-Triiodothyronine $\left(\mathrm{T}_{3}\right)$ determined
\end{abstract}

different biological responses (inhibition of cell adhesion, induction of migration, and increase in the expression of the neuronal marker neurofilament-M and $\mathrm{Na}^{+}$and $\mathrm{Ca}^{2+}$ channel functionality) in both FNC and hMSC, which express $\mathrm{TH}$ receptors. Then, we showed that $\mathrm{TH}$ significantly increase the expression levels of seladin-1, and that $\mathrm{T}_{3}$ effectively prevents camptothecin-induced apoptosis. However, in hMSC-derived neurons the expression of seladin-1 was not affected by $\mathrm{TH}$. Our results demonstrated for the first time that seladin-1 is a novel TH-regulated gene in neuronal precursors. In view of its anti-apoptotic activity, it might be hypothesized that one of the functions of the increased seladin-1 levels in the developing brain may be to protect neuronal precursor cells from death.

Journal of Endocrinology (2008) 197, 437-446

\section{Introduction}

Thyroid hormones (TH) play a fundamental role in fetal life, particularly in promoting brain development. TH affect the expression of several genes, which are related to cell migration (i.e. reelin, laminin, tenascin C), myelination (i.e. myelin basic protein, proteolipid protein, myelin-associated glycoprotein), and neuronal differentiation (i.e. nerve growth factor (NGF), brain-derived neurotrophic factor (BDNF); König \& Neto 2002, Santisteban \& Bernal 2005). In addition, a time-regulated activity of type II and III iodothyronine deiodinases (D2 and 3) in different brain areas is essential during brain development (Kester et al. 2004). Accordingly, it has been shown that early maternal hypothyroxinemia alters fetal brain histogenesis and cytoarchitecture in rats (Lavado-Autric et al. 2003), and unrecognized hypothyroidism in women in the first trimester of pregnancy may adversely affect the neuropsychological development of the progeny (Haddow et al. 1999, Pop et al. 2003, Morreale de Escobar et al. 2004). These observations raised the attention of the scientific community on the benefit of screening programs for assessing thyroid function in pregnant women (Allan et al. 2000, de Escobar 2001, Redmond 2002, Surks et al. 2004).

Selective Alzheimer's disease indicator-1 (seladin-1) is a gene which has been identified a few years ago and which has been found to be down-regulated in brain regions affected by Alzheimer's disease (AD). Conversely, in vitro overexpression of seladin-1 conferred protection against $\beta$-amyloid-mediated toxicity and from oxidative stress (Greeve et al. 2001, Kuehnle et al. 2008). The neuroprotective effect of seladin- 1 appears to be due, at least in part, to the inhibition of caspase 3 activity, a key mediator of apoptosis (Greeve et al. 2001). We have 
demonstrated that estrogen and the estrogen receptor modulators, raloxifene and tamoxifen, protect fetal human neuroepithelial cells (FNC) from $\beta$-amyloid and $\mathrm{H}_{2} \mathrm{O}_{2}$ toxicity by increasing the expression of seladin-1 (Benvenuti et al. 2005, Luciani et al. submitted). These cells were isolated, cloned, and propagated previously from fetal olfactory epithelium (Vannelli et al. 1995). FNC cells show unique features, because they synthesize both neuronal proteins and olfactory markers and respond to odorant stimuli, suggesting their origin from the stem cell compartment that generates mature olfactory receptor neurons. In addition, we have recently demonstrated that high levels of expression of seladin-1 were detectable in human mesenchymal stem cells (hMSC), whereas a significant reduction was observed in hMSC-derived neurons (hMSC-n; Benvenuti et al. 2006). We have also detected high levels of seladin-1 transcript in the adult hippocampus (Benvenuti et al. 2006), one of the brain areas affected in AD (Selkoe 2001), in which stem cells with a defined neurogenic potential are located in the adult brain (Lie et al. 2004). These findings suggest that seladin-1 is a predominant product of multipotent cells and that the defective seladin-1 expression detected in AD-vulnerable brain regions may be linked to an impaired neuronal stem cell compartment, which could be a potential risk factor for the development of this disease. Interestingly, there is evidence both in embryonic and in adult mammals that TH plays a key role in the development and maintenance of basal forebrain cholinergic neurons typically involved in AD (Patel et al. 1987, Calzàet al. 1997).

Therefore, we hypothesized that seladin-1 may be one of the mediators of the effects of TH during the development of the nervous system. According to this hypothesis, in the present study, we first determined the role of TH on cell differentiation in FNC and hMSC, by addressing their effects on cell adhesion, invasiveness, expression of the neuronal marker neurofilament$\mathrm{M}, \mathrm{Na}^{+}$and $\mathrm{Ca}^{2+}$ channels functionality as evaluated by their current density, and activation and inactivation voltage dependence. Thereafter, we analyzed whether TH affect the expression of seladin-1 in these cells and prevent apoptosis. In order to clarify whether seladin-1 may be targeted as a $\mathrm{TH}$-regulated gene selectively in neuronal precursors, the effect of TH on seladin- 1 expression was also determined in hMSC-n.

\section{Materials and Methods}

\section{Materials}

Media and sera for cell cultures were purchased from Euroclone (Wetherby, West York, UK) and tissue plasticware was obtained from GreinerBio-One (Frickenhausen, Germany). The neurobasal medium was obtained from Life Technologies (Invitrogen). Other reagents for cell cultures were obtained from Sigma. The flow cytometry buffer (CellWASH) was obtained from Becton Dickinson (Franklin Lakes, NJ, USA). Monoclonal antibodies for flow cytometry immunophenotyping were obtained from BD Pharmingen
(San Diego, CA, USA) and Ancell (St N Bayport, MN, USA), whereas antibodies for immunocytochemistry were from Chemicon (Temecula, CA, USA). For RNA extraction, the Nucleospin RNAII kit was purchased from MachereyNagel (Duren, Germany). Reagents for RT-PCR studies were from Applied Biosystem Inc. (Foster City, CA, USA). $\mathrm{TH}\left(3,3^{\prime}, 5\right.$-triiodothyronine, $\mathrm{T}_{3}$ and $\mathrm{L}$-thyroxin, $\left.\mathrm{T}_{4}\right)$ and camptothecin were purchased from Sigma. Molecular weight marker GeneRuler 100 and 50 bp DNA Ladder were from Fermentas (Burlington, Ontario, Canada).

\section{Cell cultures}

FNCs were isolated from human fetal olfactory neuroepithelium, as described previously (Vannelli et al. 1995). Long-term FNC cell cultures were propagated in Coon's-modified Ham's F12, supplemented with 10\% fetal calf serum (FCS) and antibiotics (growth medium). The B4 clone, showing the highest level of the expression of neuronal and olfactory markers, was used in this study. hMSC were isolated from the iliac crest of normal donor marrow aspirates. Informed consent was obtained from all donors and the institutional ethical committee approved all the procedures. hMSC were isolated and characterized as described previously (Benvenuti et al. 2006). The induction of a neuronal phenotype in hMSC was performed according to the method of Woodbury et al. (2000), with some modifications, as described previously (Benvenuti et al. 2006).

\section{RT-PCR for TH receptors (TR) and type $I$ and II deiodinases (D1 and D2)}

Total RNA was isolated from FNC, hMSC, and hMSC-n. RT-PCR was performed using SuperScript III One-Step RT-PCR with Platinum Taq kit (Invitrogen Life Technologies Inc.) with $1 \mu \mathrm{g}$ total RNA as template. Specific oligonucleotides were used as upstream and downstream primers, as described previously (Gittoes et al. 1997, de Souza Meyer et al. 2005). All reactions were performed in duplicate. After amplification, $10 \mu \mathrm{l}$ aliquots of the PCR products were analyzed on a $2 \%$ ethidium bromide agarose gel and visualized under u.v. light using Kodak Image Station 140 CF.

\section{Cell adhesion assay}

For cell adhesion assay, the cells were plated in 96-well plates at a density of $5 \times 10^{4}$ (hMSC) cells/well and $6 \times 10^{4}$ (FNC) cells/well with or without $1 \mathrm{nM} \mathrm{T}_{3}$ in medium with $1 \% \mathrm{FCS}$ for $24 \mathrm{~h}$. At the end of the incubation, the cell monolayer was washed twice with PBS in order to remove the non-adherent cells by aspiration and $100 \mu \mathrm{l}$ Rose Bengal stain $(0 \cdot 25 \%$ in PBS) was added to each well for $5 \mathrm{~min}$ at room temperature (Gamble \& Vadas 1988). After aspiration of the stain, each well was washed twice in PBS and the stain was released by adding $200 \mu \mathrm{l} /$ well of an ethanol/PBS (1:1) solution for $30 \mathrm{~min}$. The samples were analyzed using an ELISA plate 
reader (Seac-Radim) at $570 \mathrm{~nm}$ wavelength and the results were expressed as optical density (OD)/well (mean \pm s.E.M). The experiments were performed in hexaplicate and were repeated at least three times.

\section{Quantitative cell migration assay}

hMSC and FNC cells were passaged twice prior to the assay and were washed with PBS. Successively, the cells were detached using a harvesting buffer $(0 \cdot 05 \%$ trypsin in Hank's balanced salt solution containing $25 \mathrm{mM}$ HEPES), and a quenching medium (serum-free Dulbecco's modified minimum essential medium (DMEM) containing 5\% BSA) was added to the dishes. After centrifugation, the cells were resuspended in the quenching medium and $500 \mu \mathrm{l}$ cell suspension, with or without $1 \mathrm{nM} \mathrm{T}$, was added to both collagen I- and BSA-coated Boyden chambers (top). The same number of cells was plated in collagen I-coated wells for cell adhesion and morphology control. After $20 \mathrm{~h}$ incubation, the cells were stained using crystal violet according to the manufacturer's instructions. Finally, $300 \mu \mathrm{l}$ extraction buffer was added to each membrane for $15 \mathrm{~min}$, then a $50 \mu \mathrm{l}$ stained solution was removed and placed in 96-multiwell plates, and the absorbance was read at $540 \mathrm{~nm}$.

\section{Immunocytochemistry}

hMSC were cultured in four-chamber slides in a growth medium. Subsequently, the cells were treated with $1 \mathrm{nM} \mathrm{T}$ for 4 days in a serum-free medium. Then, they were washed twice with PBS, fixed in $4 \%$ paraformaldehyde and $0 \cdot 1 \%$ glutaraldehyde, and were immunostained for neurofilamentM (NF-M) using a rabbit anti-NF-M C-terminal antibody $(1: 1000)$. The cells were incubated overnight at $4{ }^{\circ} \mathrm{C}$ with the primary antibody, followed by a $1 \mathrm{~h}$ incubation with a peroxidase-conjugated secondary antibody. Finally, the cells were exposed to Vectastain ABC and AEC reagents (Vector Laboratories Inc., Burlingame, CA, USA) and counterstained with hematoxylin. Immunopositive cells/field were counted in ten $40 \times$ fields for each experiment $(n=3)$ and the results were expressed as mean \pm s.E.M.

\section{Electrophysiological studies}

The electrophysiological records were obtained on FNC and hMSC (control and $\mathrm{T}_{3}$-treated) adherent on glass cover slips using the whole-cell patch-clamp technique under voltageclamp conditions. The experimental setup, microelectrodes, pulse protocols of stimulation, data acquisitions, and analysis were as previously described in detail (Benvenuti et al. 2006). When outward $\mathrm{K}^{+}$currents had to be suppressed, parallel experiments were performed using a $20 \mathrm{mM}$ TEA solution containing $122.5 \mathrm{mM} \mathrm{NaCl}, 2 \mathrm{mM} \mathrm{CaCl}, 20 \mathrm{mM}$ TEA$\mathrm{OH}$, and $10 \mathrm{mM}$ HEPES. To test the high-voltage-activated $\mathrm{Na}^{+}$channels' sensitivity, TTX $(1 \mu \mathrm{M})$ was used. In order to have $\mathrm{Ca}^{2+}$ as the only permeant cation, $\mathrm{Ca}^{2+}$ currents were recorded in a TEA-Ca ${ }^{2+}$ bath solution, $10 \mathrm{mM} \mathrm{CaCl}_{2}$,
$145 \mathrm{mM}$ TEABr, and $10 \mathrm{mM}$ HEPES. In turn, $10 \mu \mathrm{M}$ nifedipine or $100 \mu \mathrm{M} \mathrm{Cd}^{2+}$, added as $\mathrm{CdSO}_{4}$, were used to block L-type $\mathrm{Ca}^{2+}$ channels and all but T-type $\mathrm{Ca}^{2+}$ channels respectively. The steady-state ionic current activation was evaluated using

$$
I_{\mathrm{a}}(V)=G_{\max }\left(V-V_{\text {rev }}\right) /\left\{1+\exp \left(\left(V_{\mathrm{a}}-V\right) / k_{\mathrm{a}}\right)\right\}
$$

and the steady-state inactivation using

$$
I_{\mathrm{h}}(V)=I /\left\{1+\exp \left(-\left(V_{\mathrm{h}}-V\right) / k_{\mathrm{h}}\right)\right\}
$$

where $G_{\max }$ is the maximal conductance for $I_{\mathrm{a}}, V_{\text {rev }}$ is the apparent reversal potential, $V_{\mathrm{a}}$ and $V_{\mathrm{h}}$ are the potentials that elicit the half-maximal size, and $k_{\mathrm{a}}$ and $k_{\mathrm{h}}$ are the steepness factors. For the activation curve evaluation, the cell was held at $-80 \mathrm{mV}$ and step pulses $\left(10 \mathrm{~ms}\right.$ or $1 \mathrm{~s}$ for $\mathrm{Na}^{+}$current, $I_{\mathrm{Na}}$, and $\mathrm{Ca}^{2+}$ current, $I_{\mathrm{Ca}}$, recording respectively) ranging from -70 to $50 \mathrm{mV}$ were applied in increments of $10 \mathrm{mV}$. The inactivation curve was evaluated on the current elicited by a voltage step at $0 \mathrm{mV}$, pre-pulsed by voltage steps as those used for activation with an inter-pulse period of 2 or $20 \mathrm{~ms}$ for $I_{\mathrm{Na}}$ and $I_{\mathrm{Ca}}$ recording respectively. Data are expressed as mean \pm s.E.M.

\section{Quantitative real-time $R T-P C R$}

The quantification of seladin-1, integrin subunits $\alpha \mathrm{V}, \beta 3$, and $\alpha 2 b$ mRNA, was performed by real-time RT-PCR, based on TaqMan technologies. The total RNA to be subjected to RT was extracted from FNC, hMSC, and hMSC-n (basal conditions and after $T_{3}$ or $T_{4}$ treatment for $72 \mathrm{~h}$ in serumfree medium). Total RNA isolation and cDNA synthesis were obtained as reported previously (Luciani et al. 2004). The primers and probe for the integrin subunits $\alpha \mathrm{V}, \beta 3$ and $\alpha 2 \mathrm{~b}$ were Assay-On-Demand gene expression products (Applied Biosystems); the PCR mixture (25 $\mu \mathrm{l}$ final volume) consisted of $1 \times$ final concentration of Assay-On-Demand mix, $1 \times$ final concentration of Universal PCR Master Mix (Applied Biosystems), and $20 \mathrm{ng}$ cDNA. Each measurement was carried out in triplicates and three experiments were performed. The mRNA quantification was based on the comparative $\mathrm{Ct}$ method according to the manufacturer's instructions (Applied Biosystems) and data were normalized to ribosomal 18S RNA expression. The results were expressed as percentage mRNA versus control. The conditions used for seladin-1 mRNA measurement were described previously (Luciani et al. 2004).

\section{TUNEL analysis for the determination of apoptotic cells}

Apoptosis was determined by TUNEL analysis, using a commercially available detection kit (FragEL DNA Fragmentation Detection Kit, Oncogene Research Products, Boston, MA, USA), following the manufacturer's instructions. Briefly, FNC and hMSC were cultured in chamber slides both in the presence and in the absence of $1 \mathrm{nM} \mathrm{T}_{3}$ for $72 \mathrm{~h}$. During the last $4 \mathrm{~h}$, one half of $\mathrm{T}_{3}$-treated and the other half of untreated 


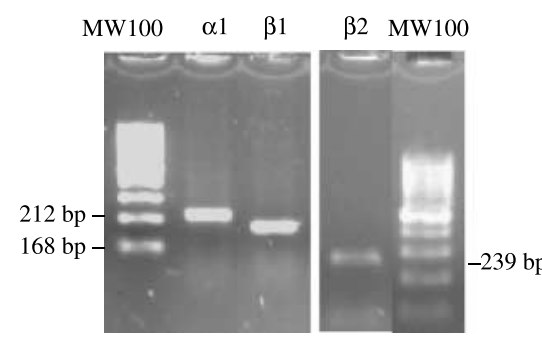

FNC

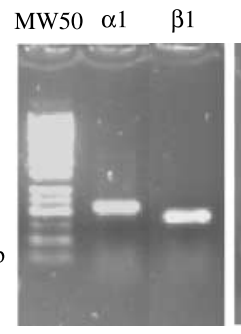

hMSC

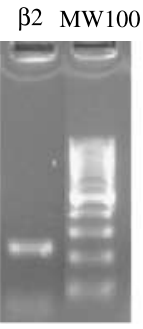

Figure 1 Detection of TR isoforms $\alpha 1, \beta 1$, and $\beta 2$ mRNA by RT-PCR in FNC and hMSC. C+, positive control,

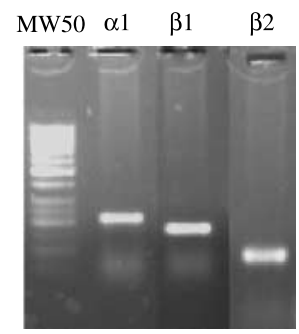

$\mathrm{C}+$ i.e. normal thyroid tissue. MW100 and MW50, molecular weight marker (see Materials and Methods).

chamber slides were exposed to $20 \mu \mathrm{g} / \mathrm{ml}$ camptothecin. Three experiments were performed. The number of apoptotic cells/field was counted in ten $20 \times$ fields for each experiment and the results were expressed as percentage of apoptotic cells/field (mean \pm s.E.M).

\section{Results}

Expression of TR in FNC and hMSC

The presence of transcripts corresponding to TR $\alpha 1, \beta 1$, and $\beta 2$ (i.e. the major TR isoforms with a known biological role) in
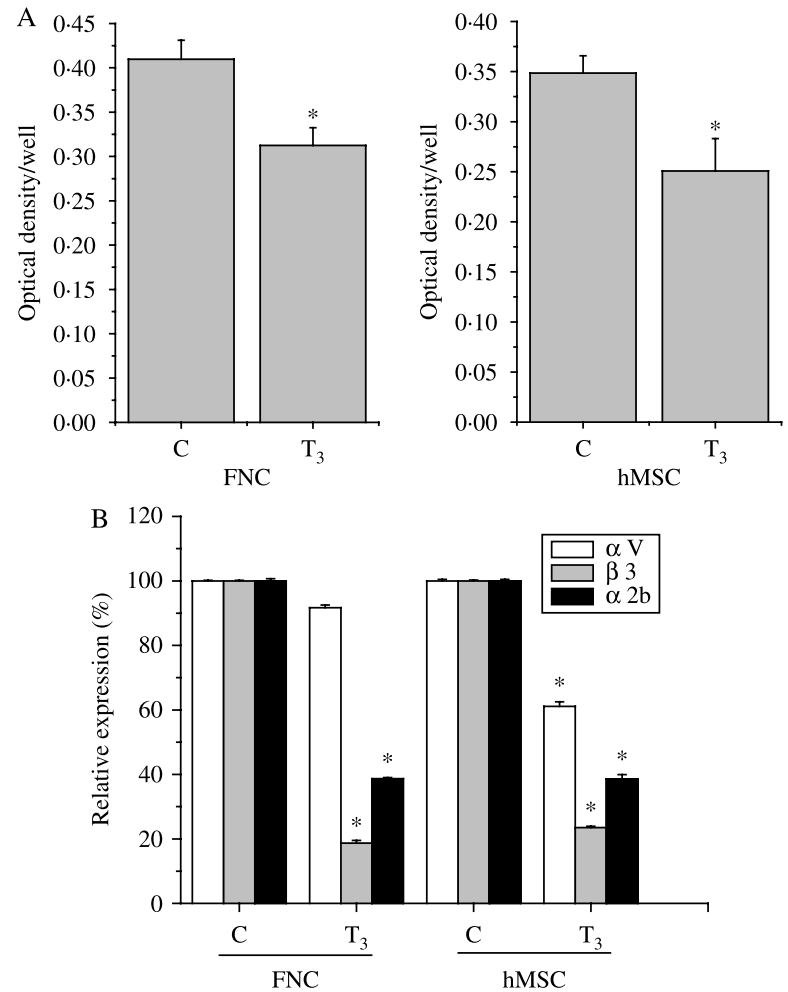

Figure 2 (A) Effect of $T_{3}(1 \mathrm{nM})$ on cell adhesion. (B) Amount of integrin subunits $\alpha \mathrm{V}, \beta 3$, and $\alpha 2 \mathrm{~b}$ mRNA in FNC and hMSC, without or with $T_{3}$ exposure. $C$, control, i.e. absence of $T_{3}$ exposure. $* P<0 \cdot 05$ vs $C$.
FNC and hMSC was evaluated by RT-PCR. In both the cases, detectable amounts of mRNA of these TR isoforms were found, as shown in Fig. 1.

Effect of $T_{3}$ on cell adhesion, migration, and expression of NF-M

No study has so far addressed the effect of TH in promoting the neuronal differentiation of FNC and hMSC. Therefore, the first objective of this study was to determine whether $T_{3}$

A

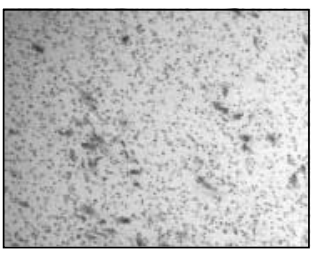

FNC

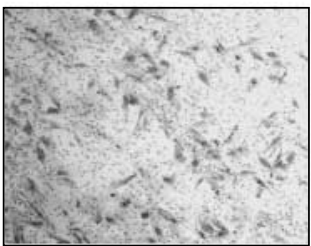

$\mathrm{FNC}+\mathrm{T}_{3}(1 \mathrm{nM})$

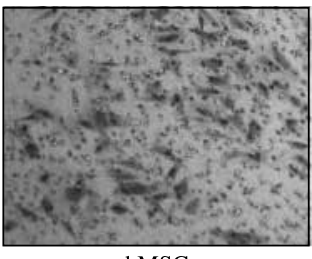

hMSC

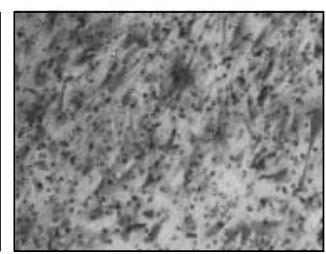

$\mathrm{hMSC}+\mathrm{T}_{3}(1 \mathrm{nM})$

B
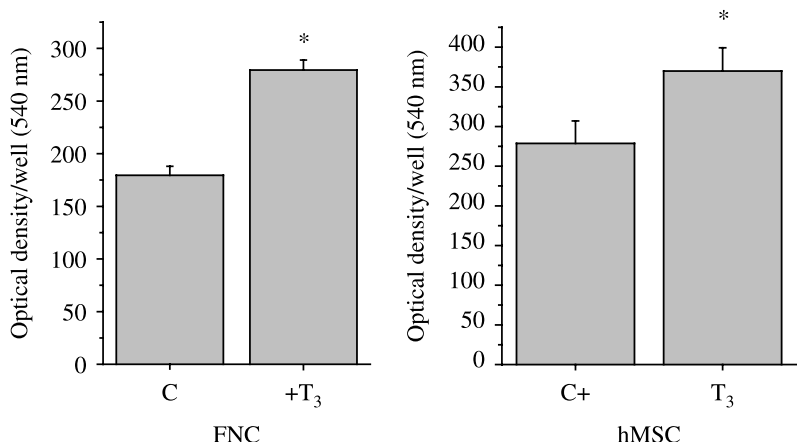

Figure 3 Effect of $T_{3}(1 \mathrm{nM})$ on cell migration in FNC and hMSC. A typical experiment is shown in $(A)$, and the quantitative analysis is represented in (B). 
induces biological responses, which are expected in differentiating cells, in our particular cell models. First, the effect of $\mathrm{TH}$ on cell adhesion was determined. The exposure to $\mathrm{T}_{3}$ $(1 \mathrm{nM})$ for $24 \mathrm{~h}$ induced a significant inhibition of cell adhesion in FNC as well as in hMSC (Fig. 2A). Accordingly, the expression of integrin subunits $\alpha 2 b, \beta 3$ and, in the case of hMSC, also $\alpha \mathrm{V}$ was significantly reduced by $\mathrm{T}_{3}$ exposure (Fig. 2B). With regard to cell migration, exposure to $1 \mathrm{nM} \mathrm{T}_{3}$ determined a significant stimulatory effect in both the cell models (Fig. 3A and B). Immunocytochemistry for the neuronal marker NF-M was also performed. In untreated FNC, positivity for NF-M was rarely observed, whereas $\mathrm{T}_{3}$-treated cells showed a strong positivity, decorating specifically both the cell body and the neurite-like processes (Fig. $4 \mathrm{~A})(8 \pm 1 \cdot 1$ vs $49 \cdot 7 \pm 6 \cdot 9$ cells/field, mean \pm s.E.M., $P<0 \cdot 005)$. Similarly, in untreated hMSC a faint positivity was observed in a few cells. Upon $\mathrm{T}_{3}$ exposure, the intensity of the staining and the number of positive cells markedly increased (Fig. 4B) $(13 \cdot 2 \pm 0.9$ vs $41 \cdot 4 \pm 3.6$ cells/field, mean \pm s.E.M., $P<0 \cdot 05)$.
Effects of $T_{3}$ on the electrophysiological properties of FNC and $h M S C$

Based on previous evidence indicating a positive effect of $\mathrm{T}_{3}$ on neuron excitability (Hoffmann \& Dietzel 2004), the effect of $\mathrm{T}_{3}$ on the electrophysiological properties of FNC and hMSC was also assessed. All control FNC exhibited $I_{\mathrm{Na}}$ as shown in a typical experiment displayed in Fig. 5A. The voltage threshold of $I_{\mathrm{Na}}$ was about $-50 \mathrm{mV}$. The treatment with $\mathrm{T}_{3}(1 \mathrm{nM}$ for $72 \mathrm{~h}$ ) definitely increased $I_{\mathrm{Na}}$ amplitude (Fig. 5B) and this was consistently observed in all the experiments. The normalized $\mathrm{I}-\mathrm{V}$ plot determined at the current peak related to all the cells investigated is shown in Fig. 5C. With regard to hMSC, these cells usually did not show a typical voltage-activated $I_{\mathrm{Na}}$. Only a low percentage $(<5 \%)$ of hMSC cultured on the glass cover slips for 3 days showed $I_{\mathrm{Na}}$ with a very small amplitude, but the $50 \%$ of hMSC cultured on the glass cover slips for 6 days showed $I_{\mathrm{Na}}$ (Fig. 5E). Again, the treatment with $\mathrm{T}_{3}(1 \mathrm{nM}$ for 6 days) determined an enhancement of $I_{\mathrm{Na}}$ (Fig. $5 \mathrm{~F}$ ) and increased the number of responsive cells to $80 \%$. The normalized I-V plot related to all the cells investigated is shown in Fig. 5G.

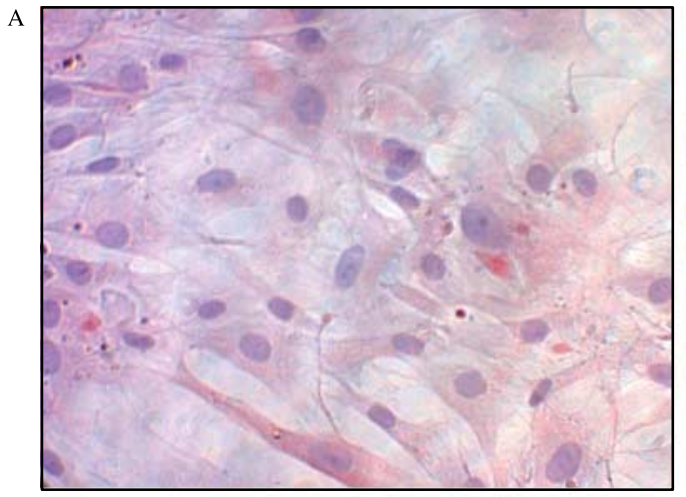

FNC

B

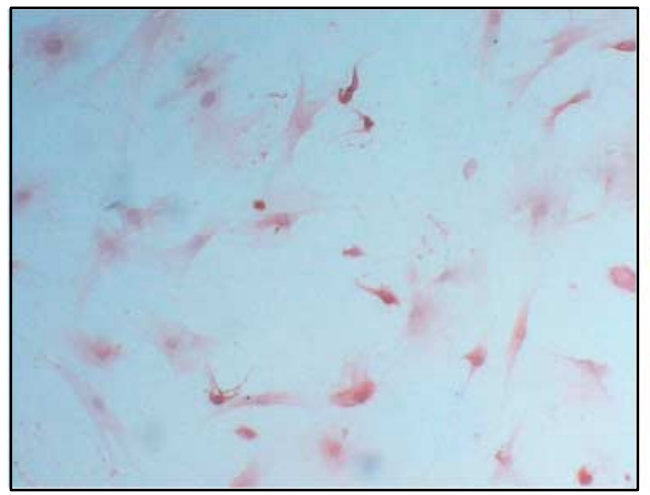

hMSC

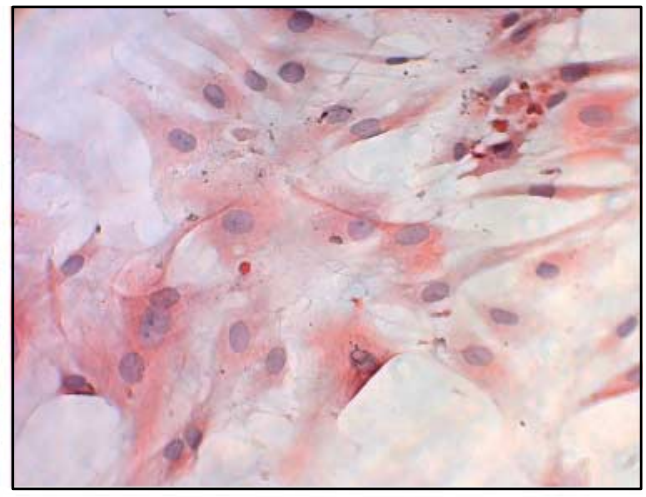

$\mathrm{FNC}+\mathrm{T}_{3}(1 \mathrm{nM})$

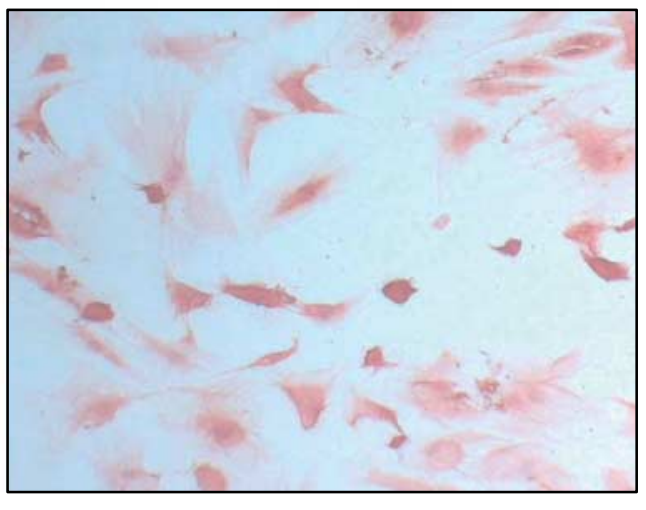

$\mathrm{hMSC}+\mathrm{T}_{3}(1 \mathrm{nM})$

Figure 4 Immunostaining for NF-M in (A) FNC and (B) hMSC in basal conditions or after exposure to $\mathrm{T}_{3}$. Magnification $40 \times$. 

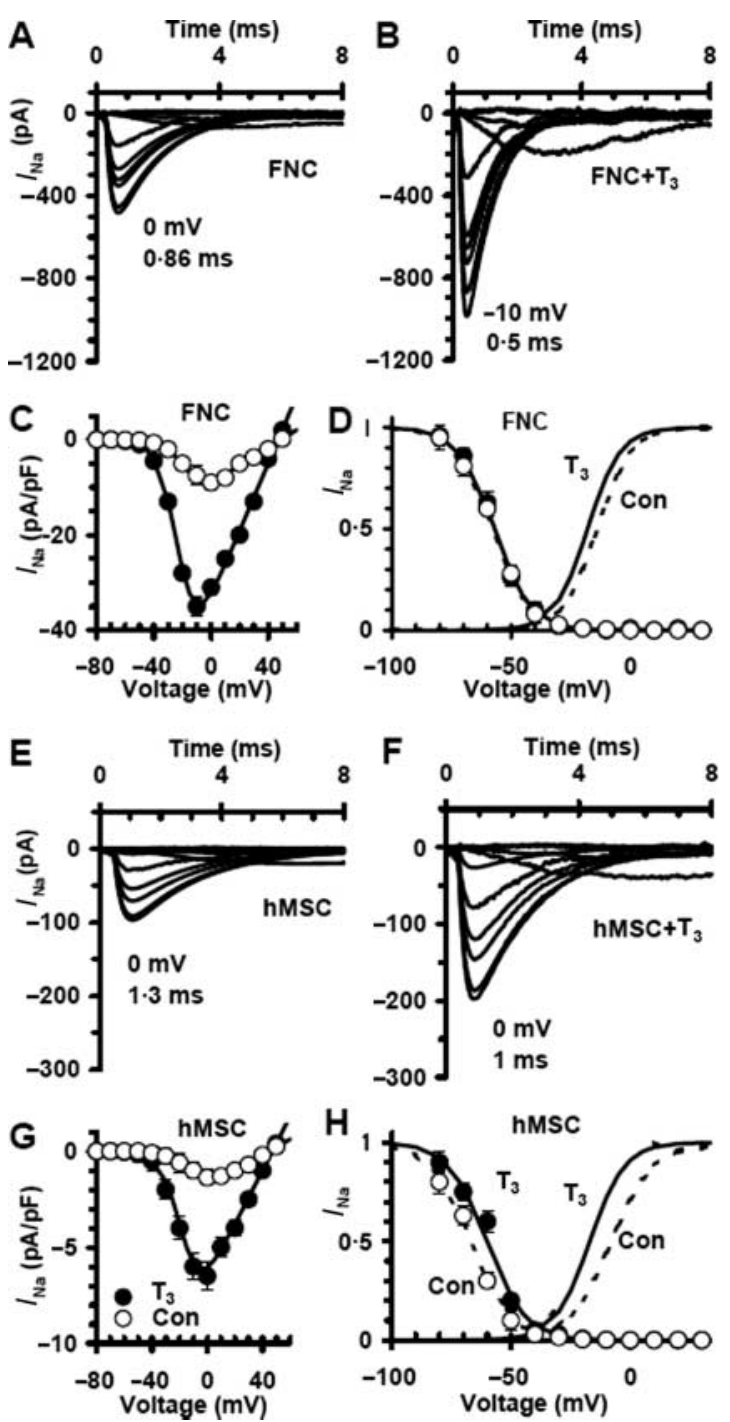

Figure 5 Inward $\mathrm{Na}^{+}$currents in FNC and hMSC. Representative $I_{\mathrm{Na}}$ traces recorded in $20 \mathrm{mM}$ TEA solution obtained from $\mathrm{FNC}$ in (A) control condition and (B) $\mathrm{T}_{3}$-treated FNC; for clarity, only current traces elicited by depolarization from -60 to $+30 \mathrm{mV}$ in increments of $10 \mathrm{mV}$ are shown. (C) Normalized I-V plots determined at the current peak in control FNC ( $n=16$, open circles) and under $\mathrm{T}_{3}$ treatment ( $n=17$, filled circles). (D) Normalized inactivation data in control FNC (open circles) and under $\mathrm{T}_{3}$ (filled circles) treatment which superimposed the related Boltzmann fit (dashed lines for control and continuous lines for $T_{3}$ ); the related Boltzmann curves for activation are obtained from fits in C. Representative $I_{\mathrm{Na}}$ traces recorded from hMSC cultured for 6 days on glass cover slips (E) and in $\mathrm{T}_{3}$-treated hMSC (F). G. Normalized $\mathrm{I}-\mathrm{V}$ plots determined at the current peak in control hMSC $(n=12$, open circles) and under $\mathrm{T}_{3}$ treatment ( $n=15$, filled circles). $\mathrm{H}$. Normalized inactivation data in control hMSC (open circles) and under $\mathrm{T}_{3}$ (filled circles) treatment which superimposed the related Boltzmann fit (dashed lines for control and continuous lines for $T_{3}$ ); the related Boltzmann curves for activation are obtained from fits in G. In A, B, E, and F, the voltage that elicited the maximal $I_{\mathrm{Na}}$ and the corresponding time to peak are reported.
The maximal current amplitude was recorded at $0 \mathrm{mV}$ in control and $\mathrm{T}_{3}$-treated hMSC, as well as in control FNC but it was at $-10 \mathrm{mV}$ in FNC treated with $\mathrm{T}_{3}$ (Fig. 5A-C and $\mathrm{E}-\mathrm{G}$ ). Interestingly, the time to peak decreased in $\mathrm{T}_{3}$-treated cells (Fig. 5A, B and E, F). Moreover, the Boltzmann parameters underwent a change because of $\mathrm{T}_{3}$ treatment. The half voltage activation parameter, $V_{\mathrm{a}}$, was negatively shifted to $\sim 5$ (FCN) and 9 (hMSC) $\mathrm{mV}_{\text {in }} \mathrm{T}_{3}$-treated cells with respect to the control (Fig. 5D and $\mathrm{H}$; Table 1). The $\mathrm{T}_{3}$ treatment determined a decrease in the $k_{\mathrm{a}}$ values, which was not significant in FNC but was significant in hMSC $(P<0 \cdot 05)$ (Table 1$)$. $I_{\mathrm{Na}}$ inactivation in $\mathrm{T}_{3}$-treated $\mathrm{FNC}$ did not show any significant change with respect to control, whereas in hMSC a $7 \mathrm{mV}$ significant shift $(P<0 \cdot 05)$ towards more positive potentials was observed for $V_{\mathrm{h}}$. The $\mathrm{T}_{3}$ treatment did not determine a significant reduction in $k_{\mathrm{h}}$ in both FNC and hMSC (Fig. 5D and H; Table 1). In conclusion, $\mathrm{T}_{3}$ treatment determined a fast kinetics of $I_{\mathrm{Na}}$ and changed the $V_{\text {a }}$ Boltzmann parameters for activation in both FNC and hMSC. Such changes were more evident in the lessdifferentiated hMSC than in FNC, in which, together with $V_{\mathrm{a}}$, the $\mathrm{T}_{3}$ treatment also affected $k_{\mathrm{a}}$ and the $V_{\mathrm{h}}$ Boltzmann parameters for inactivation.

All control FNC exhibited $I_{\mathrm{Ca}}$ (Fig. 6A). The treatment with $\mathrm{T}_{3}\left(1 \mathrm{nM}\right.$ for $72 \mathrm{~h}$ ) definitely increased $I_{\mathrm{Ca}}$ amplitude (Fig. 6B) and this was consistently observed in all the experiments. The normalized I-V plot related to all the cells investigated is shown in Fig. 6C. $I_{\mathrm{Ca}}$ was the result of T-type (not blocked by nifedipine or $\mathrm{Cd}^{2+}$ ) and L-type $I_{\mathrm{Ca}}$ (blocked by nifedipine or $\mathrm{Cd}^{2+}$ ). The voltage that elicited the maximal L-type $I_{\mathrm{Ca}}$ was shifted towards $\sim 10 \mathrm{mV}$ more negative potentials, and the related time to peak was reduced by $\sim 100 \mathrm{~ms}$ in $\mathrm{T}_{3}$-treated cells. The related Boltzmann parameters for T-type $I_{\mathrm{Ca}}$ activation were not changed by $\mathrm{T}_{3}$ treatment (Fig. 6D; Table 1). In contrast, the parameters for L-type $I_{\mathrm{Ca}}$ activation underwent a change as a result of $\mathrm{T}_{3}$ treatment (Fig. 6D; Table 1); the values of $V_{\mathrm{a}}$ were shifted to $\sim 7 \mathrm{mV}$ towards more negative potentials $(P<0 \cdot 05)$ and those for $k_{\mathrm{a}}$ were significantly reduced $(P<0 \cdot 05)$. Again, T-type $I_{\mathrm{Ca}}$ inactivation in $\mathrm{T}_{3}$-treated FNC also did not show any significant change with respect to the control, whereas the L-type $I_{\mathrm{Ca}}$ showed a $4 \mathrm{mV}$ significant shift $(P<0 \cdot 05)$ towards more negative potentials (Fig. 6D). The $\mathrm{T}_{3}$ treatment did not determine significant changes in $k_{\mathrm{h}}$. In conclusion, $\mathrm{T}_{3}$ treatment caused in FNC a fast kinetics of L-type $I_{\mathrm{Ca}}$ and changed the $V_{\mathrm{a}}$ and $V_{\mathrm{h}}$ Boltzmann parameters for activation and inactivation respectively as observed for $I_{\mathrm{Na}}$. With regard to hMSC, in both control and $\mathrm{T}_{3}$-treated cells, $I_{\mathrm{Ca}}$ was not observed, or its size was very small respect to the noise and therefore not accurately measurable (not shown).

\section{Effect of TH on seladin-1 expression and on apoptosis}

The effect of TH on the expression of seladin-1 was assessed by real-time RT-PCR. Interestingly, $\mathrm{T}_{3}(1 \mathrm{nM})$ and, yet to a lower extent, $\mathrm{T}_{4}(1 \mathrm{nM})$ determined a significant increase of seladin-1 mRNA in FNC $\left(325 \pm 7.5 \mathrm{fg} / \mu \mathrm{g}\right.$ total RNA, $\mathrm{T}_{3} ; 225 \pm$ 
Table 1 Effect of 3,3',5-triiodothyronine $\left(\mathrm{T}_{3}\right)$ treatment on Boltzmann parameters of activation and inactivation curves for $I_{\mathrm{Na}}$ in fetal human neuroepithelial cells (FNC) and in 6 days cultured human mesenchymal stem cells (hMSC) and for $I_{\mathrm{Ca}}$ in FNC

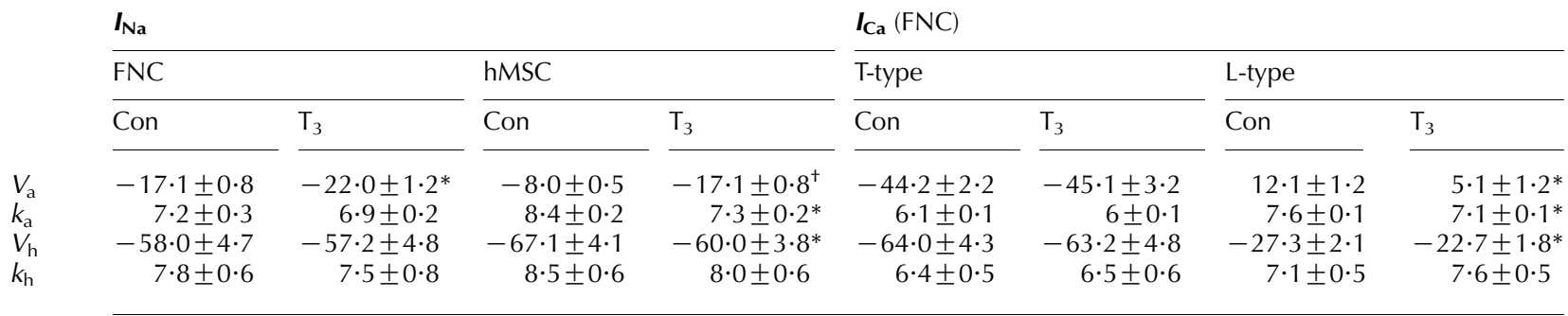

${ }^{*} P<0.05$ and ${ }^{+} P<0.01$ versus the corresponding control.

$5 \cdot 3 \mathrm{fg} / \mu \mathrm{g}$ total RNA, $\mathrm{T}_{4}$, mean \pm s.E.M. $)$ and in hMSC $(270 \pm$ $6.4 \mathrm{fg} / \mu \mathrm{g}$ total RNA, $\mathrm{T}_{3} ; 195 \pm 4.8 \mathrm{fg} / \mu \mathrm{g}$ total RNA, $\mathrm{T}_{4}$ ), when compared with the basal amount of transcript (135 \pm $2 \cdot 8 \mathrm{fg} / \mu \mathrm{g}$ total RNA in FNC; $167 \pm 3.34 \mathrm{fg} / \mu \mathrm{g}$ total RNA in
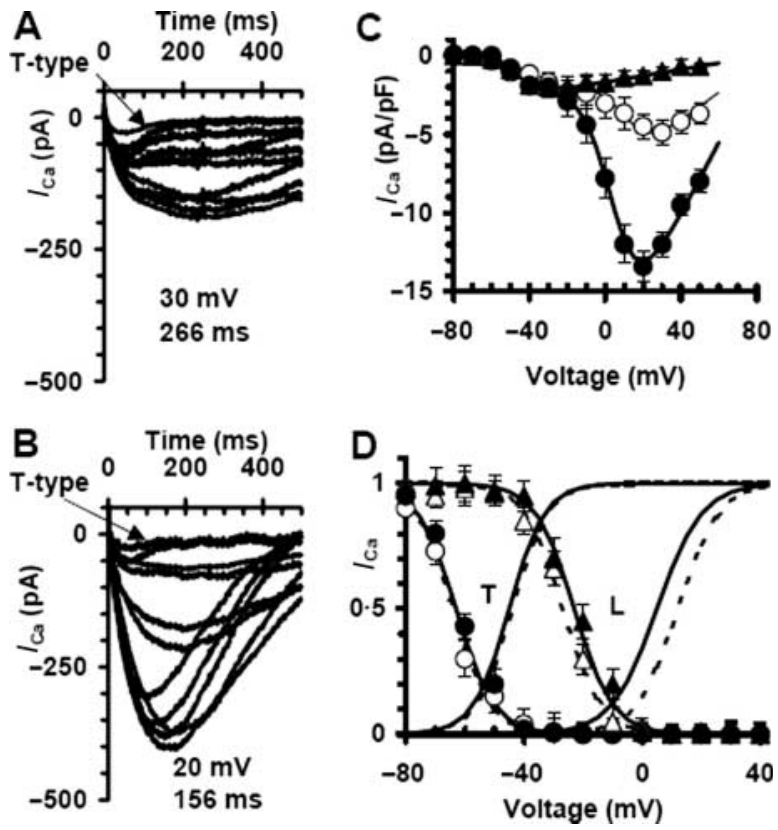

Figure 6 Inward $\mathrm{Ca}^{2+}$ currents in 6 days cultured FNC. Representative $I_{\mathrm{Ca}}$ traces recorded in TEA-Ca ${ }^{2+}$ solution obtained from FNC in (A) control condition and (B) $\mathrm{T}_{3}$-treated FNC. For clarity, only current traces elicited by depolarization from -50 to $+50 \mathrm{mV}$ in increments of $10 \mathrm{mV}$ are shown. The traces from -50 to $-30 \mathrm{mV}$ clearly show the presence of the fast activating and inactivating T-type $\mathrm{Ca}^{2+}$ current (indicated by an arrow in the $-50 \mathrm{mV}$ trace). (C) Normalized I-V plots determined at the current peak in control FNC ( $n=16$, open circles) and under $\mathrm{T}_{3}$ treatment ( $n=17$, filled circles) with superimposed curves that are the best fit as a sum of two Boltzmann functions; filled triangles represent data obtained in control FNC in the presence of nifedipine with superimposed curve that is the best fit of one Boltzmann function $(n=16)$. (D) Normalized inactivation data for T- and L-type Ca ${ }^{2+}$ current in control FNC (open circles for T-type and open triangles for L-type) and under $\mathrm{T}_{3}$ treatment (filled circles for T-type and filled triangles for L-type) which superimposed the related Boltzmann fit (dashed lines for control and continuous lines for $\mathrm{T}_{3}$ ); the related Boltzmann curves for activation are obtained from fits in C.
hMSC) (Fig. 7A). Furthermore, in agreement with previous studies associating the induction of seladin-1 expression to antiapoptotic properties (Greeve et al. 2001, Benvenuti et al. 2005, Kuehnle et al. 2008), we found that $T_{3}(1 \mathrm{nM})$ was able to significantly counteract camptothecin-induced apoptosis, as determined by TUNEL analysis, and in the case of FNC the percentage of apoptotic cells after camptothecin and $\mathrm{T}_{3}$ treatment was even superimposable with that of control cells (Table 2).

In order to determine whether the effect of $T_{4}$ was mediated by its conversion into $\mathrm{T}_{3}$, deiodinase (D1 and D2) expression was determined in FNC and hMSC by RT-PCR. Whereas no detectable amount of D1 transcript could be found in these cells, D2 transcript was present in both FNC and hMSC, as shown in Fig. 7B, thus suggesting that the stimulatory effect of $T_{4}$ on the expression of seladin-1 is, at least partially, due to the intracellular conversion into $T_{3}$.

In order to clarify whether seladin-1 may be targeted as a TH-regulated gene selectively in in vitro models of multipotent undifferentiated cells, the effect of $\mathrm{TH}$ on seladin-1 expression was also determined in differentiated neurons. For this purpose, hMSC were differentiated into a neuronal phenotype (hMSC-n) and proven to be neurons, as described previously (Benvenuti et al. 2006). In hMSC-n, the expression of detectable levels of TR $\alpha 1, \beta 1$, and $\beta 2$ was maintained (Fig. 8A). Noteworthy, the amount of seladin-1 mRNA in hMSC-n was significantly lower $(25 \pm 0.5 \mathrm{fg} / \mu \mathrm{g}$ total RNA) compared with both FNC and hMSC, thus confirming our previous finding that seladin-1 is a predominant product of undifferentiated cells (Benvenuti et al. 2006)). Furthermore, neither $T_{3}$ nor $T_{4}$ was able to modify the level of transcript in hMSC-n $(23.5 \pm 1.2 \mathrm{fg} / \mu \mathrm{g}$ total RNA, $\mathrm{T}_{3} ; 24 \pm 0 \cdot 8 \mathrm{fg} / \mu \mathrm{g}$ total RNA, $\mathrm{T}_{4}$ ) (Fig. $8 \mathrm{~B}$ ).

\section{Discussion}

It is well known that TH play a fundamental role in fetal life, particularly in promoting early brain development, by affecting the expression of specific genes (König \& Neto 2002, Santisteban \& Bernal 2005). 


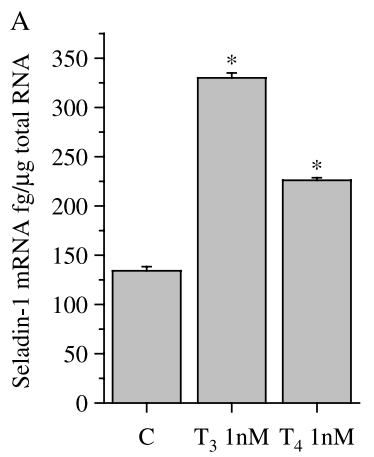

FNC

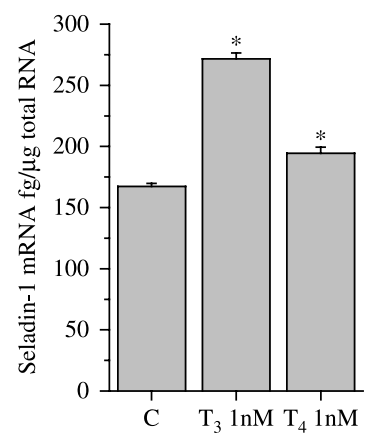

hMSC

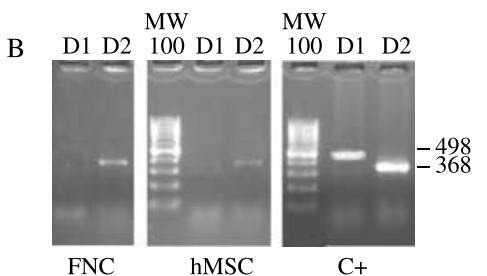

Figure 7 (A) Measurement of seladin-1 mRNA by real-time RT-PCR in FNC and hMSC, in the absence (C) or in the presence of $\mathrm{TH}$ $\left(\mathrm{T}_{3}\right.$ and $\left.\mathrm{T}_{4}\right) . * P<0 \cdot 05$ vs $\mathrm{C}$. (B) Detection of $\mathrm{D} 1$ and $\mathrm{D} 2$ mRNA in FNC and hMSC, as assessed by RT-PCR. C+, positive control, i.e. normal thyroid tissue. MW100, molecular weight marker (see Materials and Methods).

In our study, we used two different cell models, FNC and hMSC. FNC are human neuronal precursors, which generate mature olfactory receptor neurons (Vannelli et al. 1995). The choice of hMSC was based on the fact that they are much more easily obtainable than neuronal stem cells, and we rationalized that they might represent an acceptable alternative to the use of neuronal stem cells in our experimental setting. In fact, in vitro and in vivo neuronal differentiation of MSC into neurons has been demonstrated (Woodbury et al. 2000, Sanchez-Ramos 2002, Benvenuti et al. 2006). In addition, transplanted bone marrow cells have been localized in mouse (Calzà et al. 1997, Mezey et al. 2000) and human brain (Mezey et al. 2003, Weimann et al. 2003), suggesting a possible differentiation into neuronal cells. Accordingly, the functional/structural parallelism between neuronal stem cells and MSC has been underlined by

Table 2 Effect of 3,3',5-triiodothyronine $\left(\mathrm{T}_{3}\right)(1 \mathrm{nM})$ treatment on camptothecin-induced apoptosis in fetal human neuroepithelial cells (FNC) and human mesenchymal stem cells (hMSC), as determined by TUNEL analysis. The numbers represent apoptotic/total cells (mean \% \pm s.E.M.) in ten fields, magnification $20 \times$

\begin{tabular}{|c|c|c|}
\hline & FNC & hMSC \\
\hline Control & $3 \pm 1 \cdot 1$ & $2 \cdot 1 \pm 1 \cdot 1$ \\
\hline $\mathrm{T}_{3}$ & $4 \pm 0.9$ & $2 \cdot 6 \pm 1 \cdot 2$ \\
\hline Camptothecin & $15 \cdot 9 \pm 2 \cdot 4^{*}$ & $18 \cdot 1 \pm 1 \cdot 4^{*}$ \\
\hline Camptothecin $+T_{3}$ & $3 \cdot 6 \pm 0 \cdot 9^{+}$ & $7 \cdot 5 \pm 1 \cdot 6^{*,+}$ \\
\hline
\end{tabular}

${ }^{*} P<0.05$ versus control, ${ }^{+} P<0.05$ versus camptothecin. the proposal to use terms like 'neuropoiesis' to indicate the persistence of neurogenesis in the adult brain and 'brain marrow' to describe the brain regions that contain the cells supporting neurogenesis (Steindler et al. 1996, Scheffer et al. 1999).

We demonstrated that in both FNC and hMSC, which express TR $\alpha 1, \beta 1$, and $\beta 2, \mathrm{~T}_{3}(1 \mathrm{nM})$ was able to reduce cell adhesion. This finding was paralleled by the reduced expression of adhesion molecules, such as different $\alpha$ and $\beta$ integrin subunits. In addition, $T_{3}$ increased cell migration, in agreement with similar findings obtained in different cell models (König \& Neto 2002, Santisteban \& Bernal 2005). Furthermore, an increase in both the intensity of the immunostaining and in the number of positive cells for NF-M, a typical neuronal marker, was observed in hMSC and in FNC, following $\mathrm{T}_{3}$ exposure. Electrophysiological evaluation revealed that in these cell models, there were positive effects on $\mathrm{Na}^{+}$and L-type $\mathrm{Ca}^{2+}$ channels upon $T_{3}$ treatment. $T_{3}$ induced a faster activation kinetics on $I_{\mathrm{Na}}$, as indicated by the reduced time to peak, increased its current density, and shifted its activation and inactivation curves towards more negative and more positive potentials respectively. Such changes, which were more evident in hMSC than in FNC, indicated that $\mathrm{T}_{3}$ was able to induce the expression of new functional ionic channels and suggested a permissive role towards the differentiation into a proper excitable neuronal phenotype. $\mathrm{T}_{3}$ had similar effects on L-type $\mathrm{Ca}^{2+}$ channels expressed in FNC; it reduced L-type $I_{\mathrm{Ca}}$ time to peak, increased its current density and shifted its activation and inactivation curves towards more negative and more positive potentials respectively. Thus, $\mathrm{T}_{3}$ not only increased the $I_{\mathrm{Na}}$ and L-type $I_{\mathrm{Ca}}$ but also their functionality by inducing faster kinetics and changing their voltage dependence towards a more functional state. In fact, these currents activated at less negative membrane potentials and inactivated at more positive potentials. All these observations clearly indicated that $\mathrm{T}_{3}$ had biological effects on $\mathrm{Na}^{+}$and L-type $\mathrm{Ca}^{2+}$ channels in FNC, which were already committed towards neuronal differentiation. These effects were more evident on $\mathrm{Na}^{+}$channels in the lessdifferentiated hMSC, in agreement with the well-established role of TH in promoting neuronal development.

Furthermore, we determined whether $\mathrm{TH}$ affect the expression of seladin-1. We found that $\mathrm{T}_{3}$, and to a lesser extent $\mathrm{T}_{4}$, significantly increased the amount of seladin-1 mRNA in both the cell models. The fact that FNC as well as hMSC express type II deiodinase suggests that the effect of $\mathrm{T}_{4}$ on seladin-1 expression may be mainly due to its intracellular transformation into $\mathrm{T}_{3}$. Furthermore, in agreement with previous reports indicating that the up-regulation of seladin-1 expression, such as that obtained for instance upon estrogen exposure, is paralleled by an inhibitory effect on apoptotis (Greeve et al. 2001, Benvenuti et al. 2005), we demonstrated here that $\mathrm{T}_{3}$ also, in addition to its stimulatory role on seladin-1 expression, was able to significantly counteract the induction of apoptosis by camptothecin. These data suggest that seladin-1 may be a mediator of the effects that $\mathrm{TH}$ have in the brain. 
A

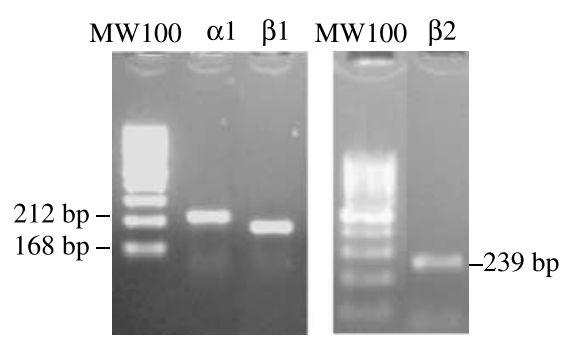

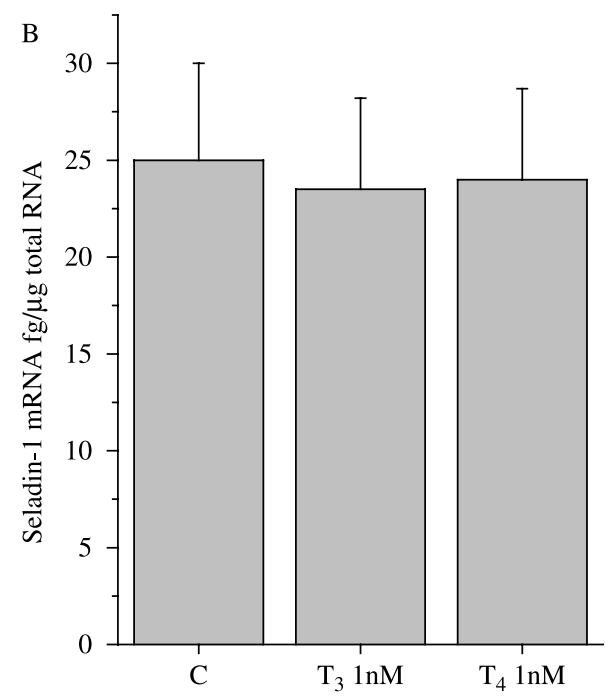

Figure 8 (A) Detection of TR isoforms in hMSC-n by RT-PCR. (B) Assessment of seladin-1 mRNA by real-time RT-PCR in hMSC-n, in the absence or in the presence of TH $\left(T_{3}\right.$ and $\left.T_{4}\right)$. MW100, molecular weight marker (see Materials and Methods).

According to the knowledge that TH play an essential role in the $\mathrm{CN}$ at the time of brain development, we questioned whether their stimulatory effect on seladin-1 expression was maintained or not in differentiated neuronal cells. Thus, we differentiated hMSC toward a neuronal phenotype (hMSC-n), according to an experimental procedure validated previously by us as well as by other groups (Woodbury et al. 2000, Benvenuti et al. 2006). Admittedly, a comparison made using the same cell model at different stages of differentiation would provide striking evidence on whether or not the expression of a gene (i.e. seladin1) is dependent on the degree of differentiation. In hMSC-n, the amount of expression of seladin-1 was significantly lower than that in hMSC, according to our previous findings (Benvenuti et al. 2006). Noteworthy, neither $T_{4}$ nor $T_{3}$ affected seladin-1 expression, thus indicating clearly that the stimulatory effect of TH appears to be selectively present in neuronal precursor cells. This finding is in keeping with observations also from in vivo studies in experimental animals that most of the TH-regulated genes are responsive only during a limited time interval of brain development (König \& Neto 2002). The molecular reason for the absent modulation of the expression of the seladin-1 gene by TH in hMSC-n, which express TR, remains elusive at present. However, the expression of TR does not necessarily correlate with the effects of TH. A good example is provided by the observation that in mice lacking the TR $\alpha 1$, which is the predominant TR isoform in the fetal cerebellum, no structural alteration of this organ was found (Morte et al. 2002). On the other hand, the presence of TR does not warrant their function on gene expression, which is the result of a complex series of events, including for instance the association with co-activators or co-repressors (Zhang \& Lazar 2000). Finally, the presence of membrane-regulated actions of TH has been described (Davis et al. 2005), and this possibility has been further highlighted by the recent demonstration of a TH cell surface receptor on the extracellular domain of integrin $\alpha \mathrm{V} \beta 3$, a structural membrane protein (Bergh et al. 2005).

The biological role played by the TH-mediated stimulation of seladin-1 expression in neuronal precursors remains to be elucidated. For this purpose, additional studies, designed for instance to make seladin-1 expression in these cells silent, will be performed, in order to determine which of the $\mathrm{TH}$-mediated function/s is/are directly due to this protein. However, in consideration of the fact that one of the best characterized properties of seladin-1 so far is its antiapoptotic activity (Greeve et al. 2001, Kuehnle et al. 2008), which has been further confirmed also by our group in FNC cells (Benvenuti et al. 2005, Luciani et al., submitted), it might be hypothesized that one of the functions associated with the increased seladin-1 levels in the developing brain may be to protect neuronal precursor cells from death. From this point of view, seladin-1 might therefore be regarded as a factor, which helps in maintaining a pool of young and self-renewing multipotent cells, to then be made available to other TH-regulated genes, which specifically direct the differentiation toward a neuronal phenotype.

In summary, our study showed for the first time that seladin-1 is a novel TH-regulated gene in neuronal precursors and suggested that it might be an additional mediator of the effects of $\mathrm{TH}$ in the developing brain.

\section{Acknowledgements}

This study was partially supported by grants from Ministero dell'Università e della Ricerca Scientifica (programmi di Ricerca Scientifica di Rilevante Interesse Nazionale, PRIN2006, 
coordinator A P), Regione Toscana (TRESOR project, responsible $\mathrm{M} \mathrm{S}$ ), and Ente Cassa di Risparmio di Firenze. The authors declare that there is no conflict of interest that would prejudice the impartiality of this scientific work.

\section{References}

Allan WC, Haddow JE, Palomaki GE, Williams JR, Mitchell ML, Hermos RJ, Faix JD \& Klein RZ 2000 Maternal thyroid deficiency and pregnancy complications: implications for population screening. Journal of Medical Screening 7 127-130.

Benvenuti S, Luciani P, Vannelli GB, Gelmini S, Franceschi E, Serio M \& Peri A 2005 Estrogen and SERMs exert neuroprotective effects and stimulate the expression of seladin-1, a recently discovered anti-apoptotic gene, in human neuroblast long-term cell cultures. Journal of Clinical Endocrinology and Metabolism 90 1775-1782.

Benvenuti S, Saccardi R, Luciani P, Urbani S, Deledda C, Cellai I, Francini F, Squecco R, Rosati F, Danza G et al. 2006 Neuronal differentiation of human mesenchymal stem cells: changes in the expression of the Alzheimer's diseaserelated gene seladin-1. Experimental Cell Research 312 2592-2604.

Bergh JJ, Lin HY, Lansing L, Mohamed SN, Davis FB, Mousa S \& Davis PJ 2005 Integrin $\alpha \mathrm{V} \beta 3$ contains a cell surface receptor site for thyroid hormone that is linked to activation of mitogen-activated protein kinase and induction of angiogenesis. Endocrinology 146 2864-2871.

Calzà L, Giardino L \& Aloe L 1997 Thyroid hormone regulates NGF content and p75LNGFR expression in the basal forebrain of adult rats. Experimental Neurology 143 196-206.

Davis PJ, Davis FB \& Cody V 2005 Membrane receptors mediating thyroid hormone action. Trends in Endocrinology and Metabolism 16 429-435.

Gamble JR \& Vadas MA 1988 A new assay for the measurement of the attachment of neutrophils and other cell types to endothelial cells. Journal of Immunological Methods 109 175-184.

Gittoes NJ, McCabe CJ, Verhaeg J, Sheppard MC \& Franklyn JA 1997 Thyroid hormone and estrogen receptor expression in normal pituitary and nonfunctioning tumors of the anterior pituitary. Journal of Clinical Endocrinology and Metabolism 82 1960-1967.

Greeve I, Hermans-Borgmeyer I, Brellinger C, Kasper D, Gomez-Isla T, Behl C, Levkau B \& Nitsch RM 2001 The human DIMINUTO/DWARF1 homolog seladin-1 confers resistance to Alzheimer's disease-associated neurodegeneration and oxidative stress. Journal of Neuroscience 20 7345-7352.

Haddow JE, Palomaki GE, Allan WC, Williams JR, Knight GJ, Gagnon J, O'Heir CE, Mitchell ML, Hermos RJ, Waisbren SE et al. 1999

Maternal thyroid deficiency during pregnancy and subsequent neuropsychological development of the child. New England Journal of Medicine 341 549-555.

Hoffmann G \& Dietzel ID 2004 Thyroid hormone regulates excitability in central neurons from postnatal rats. Neuroscience 125 369-379.

Kester MHA, Martinez de Mena R, Orregom MJ, Marinkovic D, Howatson A, Visser T, Hume R \& Morreale de Escobar G 2004 Iodothyronine levels in the human developing brain: major regulatory role of iodothyronine deiodinases in different areas. Journal of Clinical Endocrinology and Metabolism 89 3117-3128.

König S \& Neto VM 2002 Thyroid hormone actions on neural cells. Cellular and Molecular Neurobiology 22 517-544.

Kuehnle K, Crameri A, Kälin RE, Luciani P, Benvenuti S, Peri A, Ratti F, Rodolfo M, Kulic L, Heppner FL et al. 2008 Prosurvival effect of DHCR24/Seladin-1 in acute and chronic responses to oxidative stress. Molecular and Cellular Biology 28 539-550.

Lavado-Autric R, Auso E, Garcia-Velasco JV, del Carmen Arufe M, Escobar del Rey F, Berbel P \& Morreale de Escobar G 2003 Early maternal hypothyroxinemia alters histogenesis and cerebral cortex cytoarchitecture of the progeny. Journal of Clinical Investigation 111 1073-1082.

Lie DC, Song H, Colamarino SA, Ming GL \& Gage FH 2004 Neurogenesis in the adult brain: new strategies for central nervous system diseases. Annual Review of Pharmacology and Toxicology 44 399-421.
Luciani P, Ferruzzi P, Arnaldi G, Crescioli C, Benvenuti S, Valeri A, Greeve I, Serio M, Mannelli M \& Peri A 2004 Expression of the novel

adrenocorticotropin-responsive gene selective Alzheimer's disease indicator-1 in the normal adrenal cortex and in adrenocortical adenomas and carcinomas. Journal of Clinical Endocrinology and Metabolism 89 1332-1339.

Mezey E, Chandross KJ \& Harta G 2000 Turning blood into brain: cells bearing neuronal antigens generated in vivo from bone marrow. Science $\mathbf{2 9 0}$ 1779-1782.

Mezey E, Key S, Vogelsang G, Szalayova I, Lange GD \& Crain B 2003 Transplanted bone marrow generates new neurons in human brain. PNAS $1001364-1369$.

Morreale de Escobar G 2001 The role of thyroid hormone in fetal neuro development. Journal of Pediatric Endocrinology and Metabolism 14 1453-1462.

Morreale de Escobar G, Obregón MJ \& Escobar del Rey F 2004 Role of thyroid hormone during early brain development. European Journal of Endocrinology 151 U25-U37.

Morte B, Manzano J, Scanlan T, Vennström B \& Bernal J 2002 Deletion of the thyroid hormone receptor $\alpha 1$ prevents the structural alterations of the cerebellum induced by hypothyroidism. PNAS 99 3985-3989.

Patel AJ, Hayashi M \& Hunt A 1987 Selective persistent reduction in choline acetyltransferase activity in basal forebrain of the rat after thyroid deficiency during early life. Brain Research 422 182-185.

Pop VJ, Brouwers EP, Vader HL, Vulsma T, van Baar AL \& de Vijlder JJ 2003 Maternal hypothyroxinemia during early pregnancy and subsequent child development: a 3-year follow-up study. Clinical Endocrinology $\mathbf{5 9}$ 282-288.

Redmond GP 2002 Hypothyroidism and women's health. International Journal of Fertility and Women's Medicine 47 123-127.

Sanchez-Ramos JR 2002 Neural cells derived from adult bone marrow and umbilical cord blood. Journal of Neuroscience Research 69 880-893.

Santisteban P \& Bernal J 2005 Thyroid development and effect on the nervous system. Reviews in Endocrine and Metabolic Disorders 6 217-228.

Scheffer B, Horn M, Blumcke I, Laywell ED, Coomes D, Kukekov VG \& Steindler DA 1999 Marrow-mindedness: a perspective on neuropoiesis. Trends in Neuroscience 22 348-357.

Selkoe DJ 2001 Alzheimer's disease: genes, proteins, and therapy. Physiological Reviews 81 741-776.

de Souza Meyer EL, Dora JM, Wagner MS \& Maia AL 2005 Decreased type 1 iodothyronine deiodinase expression might be an early and discrete event in thyroid cell dedifferentiation towards papillary carcinoma. Clinical Endocrinology 62 672-678.

Steindler DA, Kadrie T, Fillmore H \& Thomas LB 1996 The subependymal zone: 'brain marrow'. Progress in Brain Research 108 349-363.

Surks MI, Ortiz E, Daniels GH, Sawin CT, Col NF, Cobin RH, Franklyn JA, Hershman JM, Burman KD, Denke MA et al. 2004 Subclinical thyroid disease: scientific review and guidelines for diagnosis and management. Journal of the American Medical Association 291 228-238.

Vannelli GB, Ensoli F, Zonefrati R, Kubota Y, Arcangeli A, Becchetti A, Camici G, Barni T, Thiele CJ \& Balboni GC 1995 Neuroblast long-term cell cultures from human fetal olfactory epithelium respond to odors. Journal of Neuroscience 15 4282-4294.

Weimann JM, Charlton CA, Brazelton TR, Hackman RC \& Blau HM 2003 Contribution of transplanted bone marrow cells to Purkinje neurons in human adult brains. PNAS 100 2088-2093.

Woodbury D, Schwarz EJ, Prockop DJ \& Black IB 2000 Adult rat and human bone marrow stromal cells differentiate into neurons. Journal of Neuroscience Research 61 364-370.

Zhang J \& Lazar MA 2000 The mechanism of action of thyroid hormone. Annual Review of Physiology 62 439-466.

Received in final form 13 February 2008

Accepted 15 February 2008

Made available online as an Accepted Preprint 15 February 2008 